\title{
Відкриті і закриті методи декомпресії тонкої кишки у хворих на гостру непрохідність травного каналу
}

\author{
V. V. BENEDYKT \\ I. Horbachevsky Ternopil State Medical University
}

\section{OPEN AND CLOSED DECOMPRESSION METHODS OF THE SMALL INTESTINE IN PATIENTS WITH ACUTE OBSTRUCTION OF THE DIGESTIVE TRACT}

\begin{abstract}
Порушення функції травного каналу у хворих на гостру непрохідність кишки є однією з головних причин розвитку поліорганної недостатності і несприятливих наслідків. Використання декомпресії тонкої кишки має вирішальне значення під час лікування цього захворювання. Метою є визначення ефективності різних методів декомпресії тонкої кишки у хворих на непрохідність і визначення показань до різних методів їх використання. Проведено дослідження 122 хворих на гостру непрохідність кишки і 30 медичних карт стаціонарного хворого померлих пацієнтів. У 67,21 \% випадків використано назогастроінтестинальну інтубацію, у 6,56 \% пацієнтів - одномоментну декомпресію тонкої кишки під час операції. У 5-ти випадках при виконанні релапаротомії встановлено неефективність закритої антеградної декомпресії. Запропоновано спосіб ентеростомії для використання відкритої інтубації тонкої кишки. Визначено показання до використання відкритих методів декомпресії тонкої кишки у хворих на гостру непрохідність кишки.

Dysfunction of the digestive tract in patients with acute bowel obstruction is one of the main causes of poliorhan failure and adverse effects. Use of decompression of the small intestine is crucial in the treatment of this disease. The goal is to determine the effectiveness of different methods of decompression of the small bowel in patients with obstruction and identify indications for different methods of their use. A study of 122 patients with acute bowel obstruction and 30 inpatient medical records of deceased patients was conducted. In $67.21 \%$ of cases used nasogastrointestinal intubation in $6.56 \%$ of patients - TCstage decompression during surgery. In 5 cases when performing relaparotomy there was established the inefficiency of closed antegrade decompression. A method for using open enterostomy intubation of the small intestine was offered. We defined indications for using open methods of decompression of the small intestine in patients with acute obstruction of the intestine.
\end{abstract}

Постановка проблеми і аналіз останніх досліджень та публікацій. Синдром інтоксикації, який зумовлений порушеннями функції травного каналу у хворих на гостру непрохідність кишки (ГНК), є однією з головних причин тяжкого перебігу цього захворювання і часто призводить до несприятливих результатів хірургічного лікування [4]. Декомпресія тонкої кишки (ТК) при цьому захворюванні за допомогою назогастроінтестинальної інтубації (НГІІ) або відкритих способів $є$ необхідною складовою в лікувальному комплексі [3, 5]. Досить ефективним способом декомпресії тонкої кишки (ТК) є назогастроінтестинальна інтубація [2, 8]. Водночас дані літератури [4] засвідчують випадки неефективного дренування ТК цим методом у післяопераційному періоді, а результати досліджень групи авторів [7] вказують, що до використання НГІІ треба ставитися “... 3 обережністю ... і строгих показань до її виконання немає”. Інші вказують на ефективну декомпресію травного каналу за допомогою інтубації ТК через ентеростому [1].
Отже, переваги різних методів декомпресії $є$ дискусійними і питання вибору того чи іншого способу під час операції у хворих на ГНК остаточно ще не вирішено. Разом з тим ефективна декомпресія травного каналу в післяопераційному періоді у хворих на ГНК має вирішальне значення в результаті лікування цього захворювання.

Мета роботи: визначення ефективності різних методів декомпресії тонкої кишки у хворих на ГНК, що дозволить визначити показання до різних методів їх використання.

Матеріали і методи. Ми обстежили 122 хворих на ГНК. Визначали ефективність декомпресії травного каналу, строки відновлення рухової активності ТК, якість життя пацієнтів у ранньому періоді після операції. Крім цього, проведено ретроспективний аналіз 30 медичних карт стаціонарного хворого померлих пацієнтів, хворих на ГНК.

Результати досліджень та їх обговорення. При дослідженні лейкоцитарного індексу інток- 
сикації (ЛІІ) [6] у хворих на ГНК при сприятливому перебігу післяопераційного періоду до операції він складав $(2,91 \pm 0,13)$ од. і спостерігали збільшення його величини на 1-шу і 3-тю добу після операції в 1,5 і 1,3 раза відповідно. Тільки на 6-8 добу величина ЛІІ досягала нормальних величин. У пацієнтів поява кишкових перистальтичних звуків була зареєстрована у 61,5 \% спостережень на 1-2 добу після операції, а відходження газів відбувалося у 80,3 \% хворих на 3-5 добу після операції. НГІІ було використано в 67,21 \% випадків і одномоментну декомпресію ТК під час операції у 6,56 \% пацієнтів.

У 5-ти випадках під час релапаротомії встановлено неефективність НГІІ. Ми використали запропонований спосіб ентеростомії, який полягає в тому, що дренувальну трубку вводять у привідну петлю кишки через сформований перед тим і підшитий до черевної стінки анастомоз за Брауном [9]. Спосіб ентеростомії здійснюють таким чином. Необхідну петлю ТК з'єднують між собою серосерозними швами на відстані 6-8 см у вигляді двостволки. Роблять на них два паралельних розрізи довжиною до 4 см. У необхідному для декомпресії напрямку в ТК вводять дренувальну трубку на необхідну відстань. Дистальний кінець цієї трубки занурюють між анастомозуючими ділянками тонкої кишки за допомогою серо-серозних вузлових швів (рис. 1, а, б), і в ділянці ентеротомій накладають ентеро-ентероанастомоз. Сліпий кінець цієї петлі підшиваємо до парієтальної очеревини за допомогою вузлових швів (рис. 1, в).

Підтікання кишкового вмісту не спостерігали жодного разу. Порушень пасажу кишкового вмісту не було.

В одного хворого під час релапаротомії стверджено недостатність тонко-тонкокишкового анастомозу з розвитком поширеного перитоніту. На передню черевну стінку виведені проксимальний і дистальний відрізок ТК із декомпресією привідної петлі.

Якість життя хворих у ранньому періоді після операції при використанні НГІІ була нижчою, ніж при відкритих методах декомпресії ТК, передусім за рахунок попередження бронхолегеневих ускладнень.

При проведенні ретроспективного аналізу померлих пацієнтів встановлено, що у 17 (56,67 \%) хворих було використано НГІІ, у 3 (10 \%) - декомпресію ТК за допомогою ентеростоми і в 2 (6,67 \%) випадках - одномоментну декомпресію під час операції. Причинами відмови від декомпресії травного каналу в інших випадках були тяжкий стан пацієнтів і технічні труднощі для виконання НГІІ.
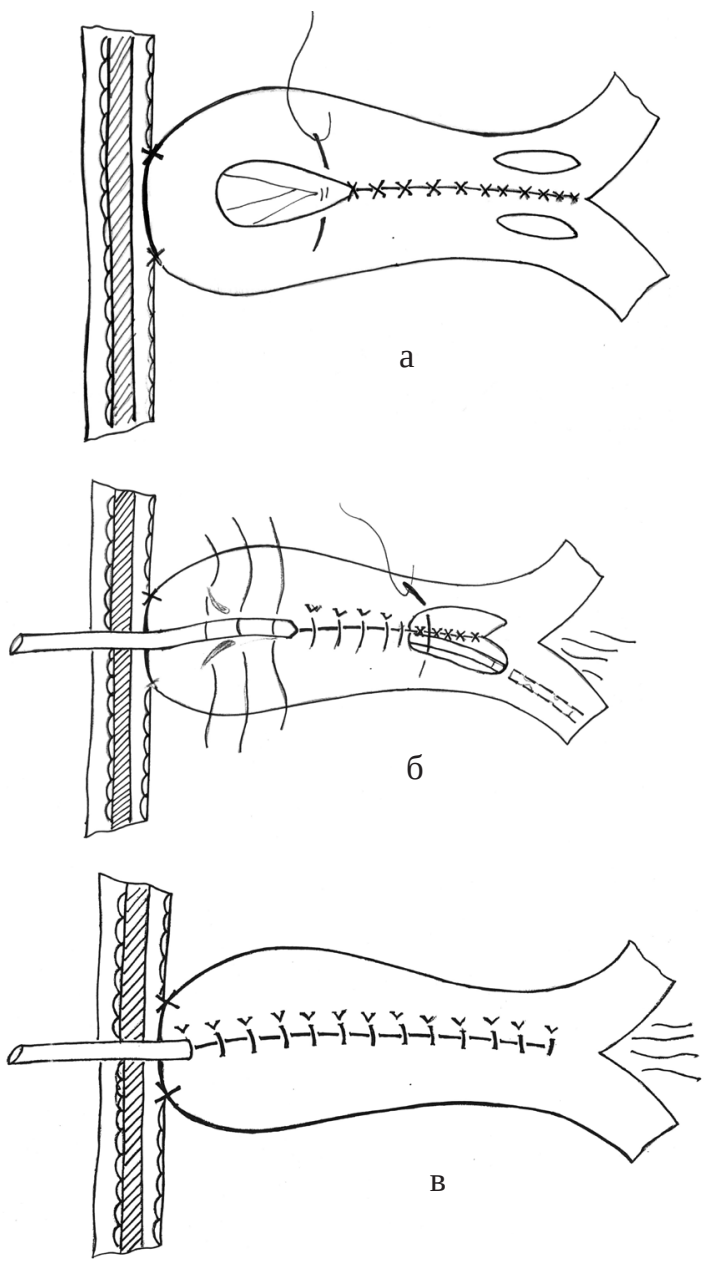

Рис. 1. Схематичне зображення запропонованої ентеростоми.

Отже, НГІІ використовували у хворих частіше відкритих методів декомпресії ТК. Наявність декомпенсованої супутньої серцево-легеневої патології у хворих, неефективність декомпресії ТK i, меншою мірою, технічні труднощі для виконання НГІІ спрямовують хірурга на необхідність за показаннями використовувати відкриті методи декомпресії.

Висновки 1. Вибір методу декомпресії тонкої кишки у хворих на гостру непрохідність травного каналу залежить від змін у тонкій кишці, конкретної інтраопераційної ситуації та функціонального стану пацієнта.

2. При ускладненому перебігу післяопераційного періоду у хворих на гостру непрохідність кишки, який супроводжується підсиленням ендогенної інтоксикації, стійким порушенням моторноевакуаторної функції травного каналу і ствердженням під час релапаротомії неефективності закритої антеградної декомпресії, доцільним є використання ретроградної відкритої інтубації тонкої кишки. 


\section{З ДОСВІДУ РОБОТИ}

3. Перспективними напрямками у вирішенні питань декомпресії тонкої кишки $є$ розробка чітких стандартів лікування хворих на гостру непро-

\section{СПИСОК ЛІТЕРАТУРИ}

1. Гаин Ю. М. Синдром энтеральной недостаточности при перитоните: теоретические и практические аспекты, диагностика и лечение / Ю. М. Гаин, С. И. Леонович, С. А. Алексеев. - Минск, 2000. - 265 с.

2. Грубник В. В. Тактичні підходи до лікування гострої кишкової непрохідності - роль і місце назоінтестинальної інтубації / В. В. Грубник, В. В. Міщенко, Ю. М. Кошель // Харківська хірургічна школа. - 2014. - № 1 (64). - С. 129-131.

3. Місце інтубації тонкої кишки в лікуванні пацієнтів з гострою злуковою кишковою непрохідністю / I. А. Даниленко, М. Г. Кононенко, Л. Г. Кащенко [та ін.] // Харківська хірургічна школа. - 2014. - № 2 (65). - С. 56-58.

4. Ерюхин И. А. Кишечная непроходимость : руководство для врачей / И. А. Ерюхин, В. П. Петров, М. Д. Ханевич. СПб. : Питер, 1999. - 448 с. хідність кишки і розширення показань до використання відкритих методів її дренування.

5. Методические аспекты назогастроинтестинальной интубации при острой хирургической патологии / Б. С. Запорожченко, И. Е. Бородаев, О. Б. Зубков [та ін.] // Харківська хірургічна школа. - 2014. - № 2 (65). - С. 66-68.

6. Кальф-Калиф Я. Я. О гематологической дифференциации различных форм и фаз острого аппендицита / Я. Я. КальфКалиф // Хирургия. - 1947. - № 7. - С. 40-43.

7. Інтубація кишечнику: критичний погляд / М. А. Мендель, Є. В. Волостников, Ю. В. Плотніков [та ін.] // Харківська хірургічна школа. - 2014. - № 1 (64). - С. 91-97.

8. Моше Шайн. Здравый смысл в неотложной абдоминальной хирургии / Шайн Моше ; пер. с англ. / под ред. Б. Д. Савчука. - М. : ГЭОТАР-МЕД, 2003. - 272 с.

9. Спосіб ентеростомії № 55573. Деклараційний патент на винахід 15.04.2003 / В. В. Бенедикт. - бюл. № 4.

Отримано 03.11.16 